nego na wciąż aktualnym problemem wieczności człowieka. Może też zobaczyć, jak Hippończyk zabiegał o ratowanie własnej duszy i jak znajdował drogę od uzasadnionego powątpiewania uczonych do niepodważalnego przekonania mędrców. Rdzeń i istota jego dowodu na nieśmiertelność duszy, da się zamknąć w jego myślowej strukturze: „Prawda, jeśli istnieje, musi być wieczna. To zaś, co jest z nią nierozdzielnie. złączone, również musi być wieczne. Matematyka i logika są prawdziwe i dlatego są złączone z rozumem, ten zaś jest nierozdzielnie złączony $\mathrm{z}$ duszą. Dlatego i dusza jest wieczna" $(12,19)$.

Obydwie autorki przy dokonywaniu przekładów omawianych pism Augustynowych oparły się na tekście łacińskim, który przygotował Harald Fuks (München - Zürich 1986, Artemis Verlag). Literaturę specjalistyczną, w liczbie 25 pozycji, jaką autorki przekładów wykorzystały przy opracowaniu wprowadzeń i objaśnień, ukazuje umieszczony na końcu (s. 107-108), zredagowany w układzie alfabetycznym indeks autorski. Oprócz niego czytelnik ma do swojej dyspozycji jeszcze 2 pomocnicze indeksy: osób (s. 109-110) i miejsc (s. 110).

Leander Tadeusz Pietras O.S.P.P.E, Vranov nad Topl'ou, Słowacja

\title{
Ks. Stanislaw KOCZWARA, Z pokladov starovekých cirkavných dejín, Košice 2007, Vydavayel'stvo Michala Vaška, ss. 76.
}

Najnowsza publikacja ks. Stanisława Koczwary - historyka Kościoła starożytnego, wybitnego znawcy dziejów papiestwa w czasach antycznych - została wydana w języku polskim w Koszycach, pod słowackim tytułem $Z$ pokladov starovekých cirkavných dejin (Ze starożytnych dziejów Kościoła). Celem pracy, jak stwierdza autor, jest wzbudzenie jeszcze silniejszego umiłowania Kościoła, wyrażającego się ,nie tylko w słowie, ale i w czynie, polegającym na dawaniu świadectwa wierności Ewangelii" (s. 5). Słowa te w dużej mierze określają charakter publikacji: jest ona faktycznie zbiorem katechez kierowanych do współczesnych, której przedmiotem staje się starożytna historia Kościoła - kiedy to konstytuował się jego fundament, kiedy jego wyznawcy dawali chlubne świadectwo swej wiary, kiedy jego Ojcowie tworzyli podstawy chrześcijańskiej nauki. Ta najdawniejsza historia - jak wielokrotnie podkreśla autor - winna być źródłem wiedzy i drogowskazem w wielu dziedzinach życia (religijnego, społecznego, politycznego) po dzień dzisiejszy.

Ks. S. Koczwara skupia się na trzech kwestiach, które przedstawia w kolejnych częściach. Pierwszą jest „Prymat św. Piotra w starożytności” (s. 12-33), zagadnienie szczególnie bliskie Autorowi, bo temu tematowi poświęcił monografię pt. Kościół Afrykański wobec Katedry Świętego Piotra (Wydawnictwo Diecezjalne w Sandomierzu, Sandomierz -Wilno 2006, ss. 358). Pojęcie prymatu definiuje jako „wypełnienie przez Chrystusa, niewidzialnej Głowy Kościoła, zbawienia, które dokonuje się z Jego woli, w sposób widzialny, poprzez posługę św. Piotra 
i jego następców na Rzymskiej Stolicy" (s. 12; por. Kościót Afrykański, s. 132). A to znaczy, iż prymat w sposób istotny związany jest ze zbawczą misją Chrystusa i stanowi fundament Kościoła. Na tych przesłankach Autor powołując się na słowa pisarzy starożytnych - Orygenesa, Leona Wielkiego, Optata z Milewy oraz współczesnych $-\mathrm{Cz}$. Bartnika, J. Śrutwy) formułuje teologiczną prawdę o jego powszechności i jedności, opartej na sukcesji: Piotr, a później jego następcy, staje się tutaj zwornikiem, jednoczącym wszystkich wiernych z Chrystusem. Jako historyk Autor ujmuje kwestię prymatu Piotra również w aspekcie dziejowym, ukazując w tym kontekście Apostoła jako „genialnego polityka”, właściwie odczytującego wolę Zbawiciela i w związku z tym świadomie wiążącego Kościół $\mathrm{z}$ uniwersalizmem kultury antycznej. Według Autora decyzja Piotra była o tyle brzemienna, że kultura ta stała się intelektualną bazą misyjnej działalności jego oraz jego następców, zaś Rzym na trwałe ich stolicą. W związku z tym Autor przybliża sylwetki trzech wybitnych sukcesorów Piotra z czasów starożytnych: Klemensa I (91-101) - gdyż to jemu Piotr przekazał biskupstwo Rzymu (wg tradycji poświadczonej przez Tertuliana i Hieronima), Stefana I (254-257) - był bowiem pierwszym, który swoją posługę na Rzymskiej Stolicy związał z sukcesją św. Piotra i wreszcie Damazego I (366-384) - gdyż pomimo wielu przeciwności umocnił autorytet biskupa Rzymu.

W drugiej części Autor omawia „Świadectwo męczeństwa w starożytności” (s. 34-57). O męczennikach uczy, iż są to najpiękniejsze postacie Kościoła, bowiem swoim fizycznym i duchowym cierpieniem oraz ofiarą życia chcą ,wykazać boskość religii Chrystusowej oraz jej uniwersalizm" (s. 35). Męczenników dzieli na trzy grupy. Pierwszą stanowią ci (a ich liczba przeszła w tysiące), którzy doznali męczeństwa od pogan (przykładem są Perpetua i Vettius Epagatus). Druga grupa to męczennicy, którzy doznali cierpień ze strony władców chrześcijańskich, uzurpujących sobie władzę nad Kościołem (ilustracją jest przypadek papieża Marcina I i cesarza Konstansa II). Trzecia grupa to ci, którzy z powodu wierności zasadom Ewangelii, stali się ofiarami swoich współwyznawców (przykład Grzegorza z Nazjanzu i jego adwersarzy - biskupów Egiptu i Macedonii oraz - pochodzące z późniejszego okresu - świadectwo św. Cyryla nękanego przez biskupów niemieckich Adalwina, Hemanricha i Anno). Autor, oceniając zaprezentowane tutaj postawy, zwraca uwagę na sprawiedliwy osąd, dokonywany przez samą historię. Wymownym przykładem owej sprawiedliwości jest odkrycie w XIX wieku dokumentów, identyfikujących imiona libellatyków - chrześcijan, którzy w okresie prześladowań Decjusza (249-251) przedstawili urzędowe oświadczenie o złożonych bogom ofiarach, celem uniknięcia męczeństwa (por. S. Longosz, Libellus - libellatici, EK X 939-943).

W części trzeciej zatytułowanej „Starożytne podstawy chrześcijańskiej wizji Europy Jana Pawła II" (s. 58-76)ks. St. Koczwara wskazuje na treści, które stworzyły teoretyczne podstawy apelu Papieża o powrót - w budowaniu współczesnego modelu wspólnoty państw europejskich - do wartości, na których oparły się one u zarania średniowiecza. Chodzi mianowicie - jak podkreśla ks. Koczwara 
- o triadę Prawda-Dobro-Piękno, już przez starożytnych Greków utożsamianą z Bogiem. W niej to, za pośrednictwem Syna Bożego - Jezusa Chrystusa, na trwałe zakorzenił się człowiek. Autor dodaje, iż poprzez to zakorzenienie „nabiera on „waloru Osoby, która jest miara godności czlowieka” (cytat z: Jan Paweł II, List do Rodzin; s. 61), a to znaczy, że „nosi tę miarę z sobą wszędzie, w każdym systemie ekonomiczno-politycznym, społecznym i dzięki niej staje się Osobą-Drogą, którą winien kroczyć Kościół, naród, państwa, Europa" (tamże). Interpretując dalej myśl papieską, Autor formułuje w związku z tym siedem grup praw, podkreślając, iż ze względu na swój uniwersalizm powinny one przysługiwać każdemu. Są to: prawo do pracy czyli do „czynienia sobie ziemi poddaną” (zgodnie z wolą Bożą), prawa rodziny czyli prawa do realizowania swojego „my” (zgodnie z Boskim „My” ), prawo (kobiety) do bycia ikoną Maryi czyli do rozwoju swojej kobiecości (zgodnie z wizerunkiem Theotokos), prawo do wierności sumieniu czyli do nazywania dobra dobrem a zła złem (zgodnie z Dobrem), prawo do wiedzy czyli do poznania prawdy (zgodnie z Prawdą), prawo do patriotyzmu czyli do umiłowania Ojczyzny (wypływające z IV przykazania Dekalogu), prawo do męstwa czyli do odważnego wyznawania prawdy (zgodnie z tradycją chrześcijańską).

Książka ks. S. Koczwary porusza zarówno umysł jak i serce. A to dlatego, że Autor konsekwentnie stara się łączyć dwa czynniki - wiarę i rozum - jak podkreśla: ,podług starożytnej maksymy: wierz, abyś zrozumiał, rozumuj, abyś uwierzył” (s. 5). Z tego połączenia rodzi się zakorzeniona w starożytności głęboka refleksja o powszechności i uniwersalizmie Kościoła, o konieczności dawania temu świadectwa przez jego członków (co pokazały przykłady męczenników) w każdym czasie - również współcześnie; zgodnie z prawami do wierności sumieniu i do męstwa. Na uznanie zasługuje też piękny styl wypowiedzi oraz znakomita znajomość literatury polskiej, zwłaszcza poezji Słowackiego, Krasińskiego i Norwida oraz Syrokomli, których poezją Autor ilustruje swoje wypowiedzi.

Anna Z. Zmorzanka - Lublin, KUL

\begin{abstract}
„Eat, drink and be merry” (Luke 12:19). Food and wine in Byzantium. In honour of Professor A.A.M. Bryer, ed. L. Brubaker - K. Linardou, Aldershot Hampshire 2007, Ashgate Publishing Limited, ss. 272.
\end{abstract}

Omawiany zbiór jest owocem kolejnego XXXVII, wiosennego spotkania bizantynologów (37th Annual Spring Symposium of Byzantine Studies), które odbyło się w marcu 2003 roku w Birmingham . Tom jest jednocześnie hołdem oddanym Anthony Bryerowi, z którego inicjatywy w roku 1966 odbyło się pierwsze sympozjum bizantynologiczne. Wypada w tym miejscu zwrócić uwagę na fakt, iż publikacja winna być również pojmowana jako świadectwo wzrastającego zainte- 